\title{
Effect of Promotion and Service Quality on Customer Satisfaction at PT. Surya Karya Prima in Jakarta
}

\author{
Triyadi \\ Universitas Pamulang \\ E-mail: dosen02488@unpam.ac.id
}

\begin{abstract}
Fulfillment of customer desires becomes very important in determining the quality of service, because what determines whether or not the quality of service is not producers or companies but consumers. This study aims to determine the effect of promotion and service quality on customer satisfaction at PT. Surya Karya Prima in Jakarta. The method used was explanatory research with a sample of 100 respondents. The analysis technique uses statistical analysis with regression testing, correlation, determination and hypothesis testing. The results of this study have a significant effect on customer satisfaction by $38.7 \%$, hypothesis testing obtained significance $0,000<0.05$. Service quality has a significant effect on customer satisfaction by $48.5 \%$, the hypothesis test obtained significance $0,000<0.05$. Promotion and quality of service simultaneously have a significant effect on customer satisfaction by $56.0 \%$, hypothesis testing obtained significance $0,000<0.05$.
\end{abstract}

Keywords: Promotion; service quality; customer satisfaction

\section{INTRODUCTION}

The economic development in Indonesia is increasing, especially in the field of services that are very close to the people of Indonesia, a fast and appropriate strategy is needed to overcome the intense competition in the marketing of specialized technical training services. One of the right strategies is if the company is able to provide customer satisfaction (Irwanto, Rohman, \& Noermijti, 2013).

Service Quality at PT. Surya Karya Prima ideally happens by improving services that meet customer expectations, not convoluted and providing customers with quality services. According to (Cahyani, 2016) service quality is an activity or a series of invisible activities that occur as a result of interactions between consumers and employees or other matters provided by the service provider companies intended to solve consumer problems. Meanwhile, according to (Atmaja, 2018; Moenir, 2010; Oliver, 2013) service is any action or activity that can be offered to other parties, which is basically intangible and does not result in any ownership".

PT. Surya Karya Prima should also conduct promotions that are able to attract the attention of customers and provide information that introduces customers to services. This agrees with (Kotler \& Armstrong, 2014; Philip Kotler and Gery Armstrong, 2001), promotion is an activity that communicates the benefits of a product and persuades target consumers to buy the product.

Customer satisfaction at PT. Surya Karya Prima ideally occurs when the perception of what is felt is in accordance with what is expected. Customer satisfaction as an overall after- 


\section{Jurnal Administrare: Jurnal Pemikiran Ilmiah dan Pendidikan Administrasi Perkantoran Vol. 7, No. 1, January - June 2020, Pages 65-72}

market evaluation comparing perceptions of product performance with pre-purchase expectations, (Artiningtyas, Minarsih, \& Hasiolan, 2014; Aryani \& Rosinta, 2010).

Understanding of the fulfillment of customer requirements is a condition for continuous improvement in quality and productivity in achieving total customer satisfaction (Jasmani \& Sunarsi, 2020; Rozi, 2020; Sunarsi \& Baharuddin, 2019). Fulfillment of customer desires becomes very important in determining the quality of service, because what determines whether or not the quality of service is not the producer or the company but the consumptions (Putro, Semuel, \& Brahmana, 2014; Supranto, 2001). Thus the company's service quality can find out what needs to be improved or improved to achieve the needs for customer satisfaction. PT. Surya Karya Prima in an effort to improve the quality of service companies create service standards by providing the best, proactive, and optimal service.

The real condition of the services provided by the company today from the results of the research that the author did has found several problems as shown in the table above, showing that there are still many customers who do not get fast handling, less friendly staff and difficult to understand the intent and purpose the officer. Another factor of customer satisfaction is promotion. Promotion is "one of the priority components of marketing activities that inform consumers that the company is launching new products that tempt consumers to carry out purchasing activities (Kotler \& Keller, 2009; Swastha, Basu, 2014). In this study ethically promotional activities that use HR, promo-material (brochures, samples, presentations, websites, etc.).

Customer satisfaction is an experience that is based on experience of assessments made by customers regarding the extent of their expectations of products and services that can be realized, (Artiningtyas et al., 2014; Saputra, 2013). The assessment is based on an evaluation of customer perceptions relating to the purchase experience or the value they have that facilitates the achievement of customer goals.

\section{METHOD}

The type of research used is associative, where the aim is to find out the connection between. The population in this study amounted to 100 respondents PT. Surya Karya Prima in Jakarta. The sampling technique in this study is saturated sampling, where all members of the population are sampled. Thus the sample in this study amounted to 100 respondents. In analyzing the data used the instrument test, classical assumption test, regression, coefficient of determination and hypothesis testing.

\section{RESULT AND DISCUSSION}

Customer satisfaction is an experience that is based on the experience of assessments made by customers regarding the extent of their expectations of products and services that can be realized

\section{Descriptive Analysis}


Triyadi; Effect of Promotion and Service Quality on Customer Satisfaction ...|67

In this test used to determine the highest minimum and maximum scores, ratting scores and standard deviations of each variable. The results are as follows:

Table 1

Statistical Descriptive Analysis Results

Descriptive Statistics

\begin{tabular}{lc|r|r|r|r}
\hline & N & Minimum & Maximum & The mean & Std. Deviation \\
\hline Promotion (X1) & 100 & 32 & 48 & 38.50 & 4,128 \\
\hline Quality of Service (X2) & 100 & 30 & 45 & 38.41 & 3,674 \\
\hline Customer Satisfaction (Y) & 100 & 32 & 46 & 39.27 & 3,598 \\
\hline Valid N (listwise) & 100 & & & & \\
\hline
\end{tabular}

Promotion obtained a minimum variance of 32 and a maximum variance of 48 with a ratting score of 3.85 with a standard deviation of 4.128. Quality of service obtained a minimum variance of 30 and a maximum variance of 45 with a ratting score of 3.84 with a standard deviation of 3.674. Customer satisfaction obtained a minimum variance of 32 and a maximum variance of 46 with a ratting score of 3.93 with a standard deviation of 3.598 .

\section{Multiple Regression Analysis}

This regression test is intended to determine changes in the dependent variable if the independent variable changes. The test results are as follows:

Table 2

Multiple Regression Testing Results

\begin{tabular}{|c|c|c|c|c|c|}
\hline & \multicolumn{2}{|c|}{ Coefficients ${ }^{\text {a }}$} & \multirow[b]{2}{*}{$\begin{array}{l}\text { Standardized } \\
\text { Coefficients }\end{array}$} & \multirow[b]{3}{*}{$\mathrm{t}$} & \multirow[b]{3}{*}{ Sig. } \\
\hline \multirow[b]{2}{*}{ Model } & $\begin{array}{r}\text { Unsta } \\
\text { Coe }\end{array}$ & $\begin{array}{l}\text { idardized } \\
\text { ficients }\end{array}$ & & & \\
\hline & B & Std. Error & Beta & & \\
\hline (Constant) & 9,040 & 2,733 & & 3,308 & .001 \\
\hline Promotion (X1) & 291 & .071 & .334 & 4,069 & .000 \\
\hline Quality of Service (X2) & 496 & .080 & .506 & 6,172 & .000 \\
\hline
\end{tabular}

a. Dependent Variable: Customer Satisfaction (Y)

Based on the test results in the above table, the regression equation $\mathrm{Y}=9.040+0.291 \mathrm{X} 1$ $+0.496 \mathrm{X} 2$ is obtained. A constant of 9,040 means that if there is no promotion and quality of service, there is a customer satisfaction value of 9,040 points. Promotion regression coefficient of 0.291 , this number is positive, meaning that every time there is an increase in promotion of 0.291 , customer satisfaction will also increase by 0.291 points. Service quality regression coefficient of 0.496 , this number is positive, meaning that every time there is an increase in service quality by 0.496 , customer satisfaction will also increase by 0.496 points.

\section{Correlation Coefficient Analysis}


68 | Jurnal Administrare: Jurnal Pemikiran Ilmiah dan Pendidikan Administrasi Perkantoran Vol. 7, No. 1, January - June 2020, Pages 65-72

Correlation coefficient analysis intended to determine tingk a the strength of the relationship of the independent variables on the dependent variable either partially or simultaneously. The test results are as follows:

Table 3

Test Results Correlation Coefficient Promotion of customer satisfaction.

Correlations $^{\text {b }}$

\begin{tabular}{llr|r}
\hline & & $\begin{array}{c}\text { Promotion } \\
\text { (X1) }\end{array}$ & \multicolumn{1}{c}{$\begin{array}{c}\text { Customer } \\
\text { Satisfaction (Y) }\end{array}$} \\
\hline Promotion (X1) & Pearson Correlation & 1 & $.622^{* *}$ \\
\cline { 2 - 4 } & Sig. (2-tailed) & & .000 \\
\hline Customer Satisfaction (Y) & Pearson Correlation & $.622^{* *}$ & 1 \\
\cline { 2 - 4 } & Sig. (2-tailed) & .000 & \\
\hline
\end{tabular}

**. Correlation is significant at the 0.01 level (2-tailed).

b. Listwise $\mathrm{N}=100$

Based on the test results obtained a correlation value of 0.622 means that promotion has a strong relationship to customer satisfaction.

Table 4

Correlation Coefficient Testing Results Quality of service to customer satisfaction. Correlations ${ }^{b}$

\begin{tabular}{llr|r}
\hline & \multicolumn{1}{c}{$\begin{array}{c}\text { Quality of } \\
\text { Service (X2) }\end{array}$} & $\begin{array}{c}\text { Customer } \\
\text { Satisfaction (Y) }\end{array}$ \\
\hline Quality of Service (X2) & Pearson Correlation & 1 & $.696^{* *}$ \\
\cline { 2 - 4 } & Sig. (2-tailed) & & .000 \\
\hline Customer Satisfaction (Y) & Pearson Correlation & $.696^{* *}$ & 1 \\
\cline { 2 - 4 } & Sig. (2-tailed) & .000 & \\
\hline
\end{tabular}

**. Correlation is significant at the 0.01 level (2-tailed).

b. Listwise $\mathrm{N}=100$

Based on the test results obtained by a correlation value of 0.696 means that service quality has a strong relationship with customer satisfaction.

Table 5

Test Results Correlation Coefficient Promotion and Service Quality Simultaneously to Customer Satisfaction.

Summary Model

\begin{tabular}{lrrrrr}
\hline Model & \multicolumn{2}{c}{ Summary Model } \\
\hline 1 & R & R Square & \multicolumn{2}{c}{$\begin{array}{c}\text { Adjusted R } \\
\text { Square }\end{array}$} & \multicolumn{2}{c}{$\begin{array}{c}\text { Std. Error of the } \\
\text { Estimate }\end{array}$} \\
\hline
\end{tabular}

a. Predictors: (Constant), Service Quality (X2), Promotion (X1) 
Triyadi; Effect of Promotion and Service Quality on Customer Satisfaction ...|69

Based on the test results obtained a correlation value of 0.748 means that promotion and service quality simultaneously have a strong relationship to customer satisfaction.

\section{Analysis of the Coefficient of Determination}

Analysis of the coefficient of determination is intended to determine the percentage of influence of the independent variable on the dependent variable either partially or simultaneously. The test results are as follows:

Table 6 .

Test Results for Promotion Determination Coefficient on Customer Satisfaction.

Summary Model

\begin{tabular}{lrr|rrr}
\hline Model & & \multicolumn{2}{c}{ Summary Model } \\
\hline 1 & $\mathrm{R}$ & R Square & $\begin{array}{c}\text { Adjusted R } \\
\text { Square }\end{array}$ & $\begin{array}{c}\text { Std. Error of the } \\
\text { Estimate }\end{array}$ \\
\hline
\end{tabular}

a. Predictors: (Constant), Promotion (X1)

Based on the test results obtained a determination value of 0.387 means that promotion has an influence contribution of $38.7 \%$ on customer satisfaction.

Table 7 .

Test Results for the Determination of Service Quality Coefficient on Customer Satisfaction.

Summary Model

\begin{tabular}{|c|c|c|c|c|}
\hline Model & $\mathrm{R}$ & R Square & $\begin{array}{l}\text { Adjusted R } \\
\text { Square }\end{array}$ & $\begin{array}{l}\text { Std. Error of the } \\
\text { Estimate }\end{array}$ \\
\hline 1 & $.696^{\mathrm{a}}$ & .485 & 479 & 2,596 \\
\hline
\end{tabular}

a. Predictors: (Constant), Service Quality (X2)

Based on the test results obtained a determination value of 0.485 means that service quality has an influence contribution of $48.5 \%$ on customer satisfaction.

Table 8 .

Test Results for Promotion Determination Coefficient and Service Quality on Customer Satisfaction.

Summary Model

\begin{tabular}{|c|c|c|c|c|}
\hline & & 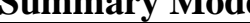 & & \\
\hline Model & $\mathrm{R}$ & R Square & $\begin{array}{c}\text { Adjusted R } \\
\text { Square }\end{array}$ & $\begin{array}{l}\text { Std. Error of the } \\
\text { Estimate }\end{array}$ \\
\hline 1 & $.748^{\mathrm{a}}$ & .560 & .551 & 2,412 \\
\hline
\end{tabular}

a. Predictors: (Constant), Service Quality (X2), Promotion (X1) 
70 Jurnal Administrare: Jurnal Pemikiran Ilmiah dan Pendidikan Administrasi Perkantoran
Vol. 7, No. 1, January - June 2020, Pages $65-72$

Based on the test results obtained a determination value of 0.560 means that simultaneous promotion and service quality has an influence contribution of $56.0 \%$ to customer satisfaction, while the remaining $44.0 \%$ is influenced by other factors.

\section{Hypothesis testing}

Hypothesis testing with $\mathrm{t}$ test is used to find out which partial hypotheses are accepted.

Table 9 .

Promotion Hypothesis Test Results on Customer Satisfaction.

Coefficients ${ }^{\text {a }}$

\begin{tabular}{|c|c|c|c|c|c|}
\hline \multirow[b]{2}{*}{ Model } & \multicolumn{2}{|c|}{ Unstandardized Coefficients } & \multirow{2}{*}{$\begin{array}{c}\text { Standardized } \\
\text { Coefficients } \\
\text { Beta }\end{array}$} & \multirow[b]{2}{*}{$\mathrm{t}$} & \multirow[b]{2}{*}{ Sig. } \\
\hline & B & Std. Error & & & \\
\hline (Constant) & 18,400 & 2,670 & & $\begin{array}{r}6,8 \\
92\end{array}$ & $\begin{array}{r}.00 \\
0\end{array}$ \\
\hline${ }_{(\mathrm{X} 1)^{\text {Promotion }}}$ & .542 & .069 & .622 & $\begin{array}{r}7,8 \\
62\end{array}$ & $\begin{array}{r}.00 \\
0 \\
\end{array}$ \\
\hline
\end{tabular}

a. Dependent Variable: Customer Satisfaction (Y)

Based on the test results in the above table, the value of $t$ count $>t$ table or (7.862>1.984) is obtained, thus the first hypothesis proposed that there is a significant influence between promotion and customer satisfaction is accepted.

Table 10

Hypothesis Test Results of Service Quality on Customer Satisfaction.

\begin{tabular}{|c|c|c|c|c|c|}
\hline \multirow[b]{2}{*}{ Model } & \multicolumn{2}{|c|}{$\begin{array}{l}\text { Unstandardized } \\
\text { Coefficients }\end{array}$} & \multirow{2}{*}{$\begin{array}{c}\text { Standardized } \\
\text { Coefficients } \\
\text { Beta }\end{array}$} & \multirow[b]{2}{*}{$\mathrm{t}$} & \multirow[b]{2}{*}{ Sig } \\
\hline & $\mathrm{B}$ & Std. Error & & & \\
\hline $\begin{array}{ll}1 & \text { (Constant) }\end{array}$ & $\begin{array}{r}13, \\
084\end{array}$ & 2,741 & & $\begin{array}{r}4 \\
, 774\end{array}$ & $\begin{array}{r}.00 \\
0\end{array}$ \\
\hline Quality of Service (X2) & 682 & .071 & 696 & $\begin{array}{r}9 \\
, 598 \\
\end{array}$ & $\begin{array}{r}.00 \\
0 \\
\end{array}$ \\
\hline
\end{tabular}

a. Dependent Variable: Customer Satisfaction (Y)

Based on the test results in table 10 , the value of $t$ count $>t$ table or $(9.598>1.984)$ is obtained, thus the second hypothesis is proposed that there is a significant influence between the quality of service on customer satisfaction received. Hypothesis testing with the F test is used to find out which simultaneous hypotheses are accepted.

Table 11 .

Promotion Hypothesis Test Results and Service Quality on Customer Satisfaction.

ANOVA ${ }^{\text {a }}$

\begin{tabular}{cc|c|c|c|c}
\hline Model & Sum of Squares & df & Mean Square & F & Sig. \\
\hline
\end{tabular}




\begin{tabular}{|c|c|c|c|c|c|c|}
\hline \multirow[t]{3}{*}{1} & Regression & 717,342 & 2 & 358,671 & 61,646 & $.000^{b}$ \\
\hline & Residual & 564,368 & 97 & 5818 & & \\
\hline & Total & 1281,710 & 99 & & & \\
\hline
\end{tabular}

a. Dependent Variable: Customer Satisfaction (Y)

b. Predictors: (Constant), Service Quality (X2), Promotion (X1)

Based on the test results on the table above, the value is $F_{\text {count }}>F_{\text {table }}$ or $(61.664>2,700)$, thus the third hypothesis proposed that there is a significant influence between promotion and service quality on customer satisfaction is received.

\section{CONCLUSION}

Based on the results of the study, promotion has a significant effect on customer satisfaction with a contribution of $38.7 \%$. Hypothesis testing obtained values of $t_{\text {coum }}>t_{\text {table }}$ or (7.862> 1.984). Service quality has a significant effect on customer satisfaction with an influence contribution of 48.5\%. Hypothesis testing obtained $t{ }_{\text {coum }}>t_{\text {wable }}$ or $(9.598>1.984)$. Promotion and service quality significantly influence customer satisfaction with a contribution of $56.0 \%$ while the remaining $44.0 \%$ is influenced by other factors. Hypothesis testing obtained the value of $\mathrm{F}_{\text {coum }}>\mathrm{F}_{\text {wable }}$ or $(61,646>2,700)$.

\section{REFERENCES}

Artiningtyas, I., Minarsih, M. M., \& Hasiolan, L. B. (2014). Kepuasan Pelanggan. Pengaruh Kualitas Layanan, Persepsi Harga Dan Kepercayaan Terhadap Kepuasan Pelanggan.

Aryani, D., \& Rosinta, F. (2010). Pengaruh Kualitas Layanan terhadap Kepuasan Pelanggan dalam Membentuk Loyalitas Pelanggan. Jurnal Ilmu Administrasi Dan Organisasi.

Atmaja, J. (2018). Kualitas Pelayanan dan Kepuasan Nasabah Terhadap Loyalitas Pada Bank BJB. Jurnal Ecodemica.

Cahyani, F. G. (2016). Pengaruh Kualitas Produk, Kualitas Pelayanan, Dan Harga Terhadap Kepuasan Konsumen. Jurnal Ilmu Dan Riset Manajemen. https://doi.org/ISSN : 24610593

Irwanto, A., Rohman, F., \& Noermijti. (2013). Analisis Pengaruh Kualitas Produk dan Strategi Harga terhadap Kepuasan Pelanggan, dan Pengaruhnya pada Terbentuknya Word-ofmouth di Perumahan Madani Group Jabodetabek. Jurnal Aplikasi Manajemen.

Jasmani, J., \& Sunarsi, D. (2020). The Influence of Product Mix, Promotion Mix and Brand Image on Consumer Purchasing Decisions of Sari Roti Products in South Tangerang. PINISI Discretion Review, 1(1), 165-174.

Kotler, P., \& Armstrong, G. (2014). Pengaruh Bauran Pemasaran Terhadap Keputusan Pembelian Rokok MILD. Jurnal Ecodemica: Jurnal Ekonomi, Manajemen, Dan Bisnis. 
72 Jurnal Administrare: Jurnal Pemikiran Ilmiah dan Pendidikan Administrasi Perkantoran Vol. 7, No. 1, January - June 2020, Pages 65-72

Kotler, P., \& Keller, K. L. (2009). Manajemen pemasaran Jilid 1. In Jakarta.

Moenir, H. A. S. (2010). Manajemen Pelayanan Umum di Indonesia. Manajemen Pelayanan Umum Di Indonesia. https://doi.org/2010

Oliver, J. (2013). Kualitas Pelayanan Publik. Journal of Chemical Information and Modeling. https://doi.org/10.1017/CBO9781107415324.004

Philip Kotler dan Gery Amstrong. (2001). Aktiviti Promosi.

Putro, S., Semuel, H., \& Brahmana, R. (2014). Pengaruh Kualitas Layanan Dan Kualitas Produk Terhadap Kepuasan Pelanggan Dan Loyalitas Konsumen Restoran Happy Garden Surabaya. Jurnal Manajemen Pemasaran.

Rozi, A. (2020). The Influence of Promotion and Distribution Accuracy on Consumer Purchase Interest in PT. Enzym Bioteknologi Internusa. PINISI Discretion Review, 1(1), 119-126.

Saputra, F. I. (2013). Kualitas Layanan , Citra dan Pengaruhnya terhadap Loyalitas melalui Kepuasan Pelanggan ( Studi Pada PT Bank Bni 46 Sentra Kredit Kecil Surabaya ). Aplikasi Manajemen. https://doi.org/10.1016/j.eneco.2016.05.009

Sunarsi, D., \& Baharuddin, A. (2019). The Effect of Service Quality and Price Accuracy on Consumer Confidence and Implications for Sales Increase. PINISI Discretion Review, $3(2), 101-110$.

Supranto. (2001). Pengukuran Tingkat Kepuasan Pelanggan. Untuk Menaikkan Pangsa Pasar. In Edisi Baru.

Swastha, Basu, I. (2014). Manajemen Pemasaran Modern. In Liberty, Yogyakarta. https://doi.org/10.1017/CBO9781107415324.004 